\title{
Effect of Oestrogen on Liver Function of Prostatic Cancer Patients
}

\author{
M. KONTTURI,* M.D. ; E. SOTANIEMI, $†$ M.D.
}

Summary : Liver function of patients with cancer of the prostate gland was studied while they were receiving oestrogen therapy. When synthetic oestrogens were given, raised values of serum aspartate and alanine aminotransferase (S.G.O.T. and S.G.P.T.) were found in about $30-50 \%$ of them. As treatment continued the increased values usually returned to normal levels. No serious liver damage was observed, though the serum bilirubin content rose temporarily in some patients.

\section{Introduction}

The effect of synthetic steroids on liver function has aroused great interest, particularly in recent years, following the hepatic dysfunction noted in connexion with the use of oral contraceptives. Usually the changes shown by liver-function tests have been mild, and reversible after termination of the therapy. Many cases of severe jaundice among women taking oral contraceptives have, however, been reported (Roman and Hecker, 1968). Most people think that liver dysfunction is probably caused by the oestrogen component (Clinch and Tindall, 1969).

Oestrogens are widely used for treatment of prostatic cancer. Some cases of icterus in patients so treated have been reported (Stirling, 1945 ; Wattenberg, 1946 ; Klosterhalfen, 1959 ; Kletschke, 1959), but most of the clinical trials have revealed no signs of hepatic dysfunction (Hagemann, 1955 ; Helrich, 1962 ; Taupitz, 1963). As the doses of oestrogen used in treating prostatic cancer are massive compared with those contained in oral contraceptives, it was decided to examine the liver function of prostatic cancer patients undergoing oestrogen therapy.

\section{Material and Methods}

The series consisted of 24 patients in whom the diagnosis had been verified histologically. Castration was carried out on all of them, after which they were given $500 \mathrm{mg}$. of stilboestrol diphosphate intravenously per day for 10 days. From the 11 th day onward they received $18 \mathrm{mg}$. of chlorotrianisene by mouth daily. The patients were kept under observation for periods of one month to a year.

The conventional tests performed (with their normal upper limits given in parentheses) were: serum aspartate aminotransferase (S.G.O.T., Wroblewsky, 40 units), serum alanine aminotransferase (S.G.P.T., Wroblewsky, 40 units), serum alkaline phosphatase (Bessey-Lowry, 2.9 units), thymol turbidity (4 units), serum bilirubin ( $1 \mathrm{mg} . / 100 \mathrm{ml}$.), and the 45 -minute bromsulphalein (B.S.P.) retention level (6\%). Laboratory tests were carried out before institution of treatment, and 4-10 days, 1 month, 4 months, and 12 months after treatment had started.

\section{Results}

Before treatment the S.G.O.T. level of seven patients was found to be increased (Fig. 1). In the course of the intravenous

* Chief Urologist, Department of Surgery, University of Oulu, Oulu,

t Senior Lecturer, Department of Medicine, University of Oulu, Oulu, Finland. therapy the S.G.O.T. values in about $50 \%$ of the patients were found to be above normal.

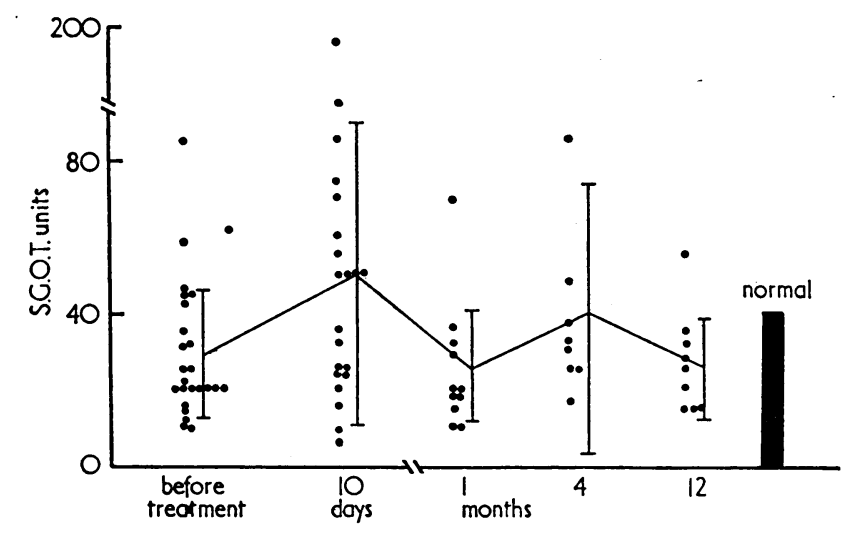

FIG. 1.-S.G.O.T. activities ( \pm S.D.) in patient's serum. The patients were given $500 \mathrm{mg}$. of stilboestrol diphosphate intravenously per day for 10 days. From the 11 th day they received $18 \mathrm{mg}$. of chlorotrianisene by mouth per day.

At the end of the follow-up period only one patient out of nine had a raised S.G.O.T. value. The S.G.O.T. values, which had been above normal level before treatment, returned to normal in three patients during oestrogen therapy. Before treatment five patients showed an increased S.G.P.T. level (Fig. 2). In

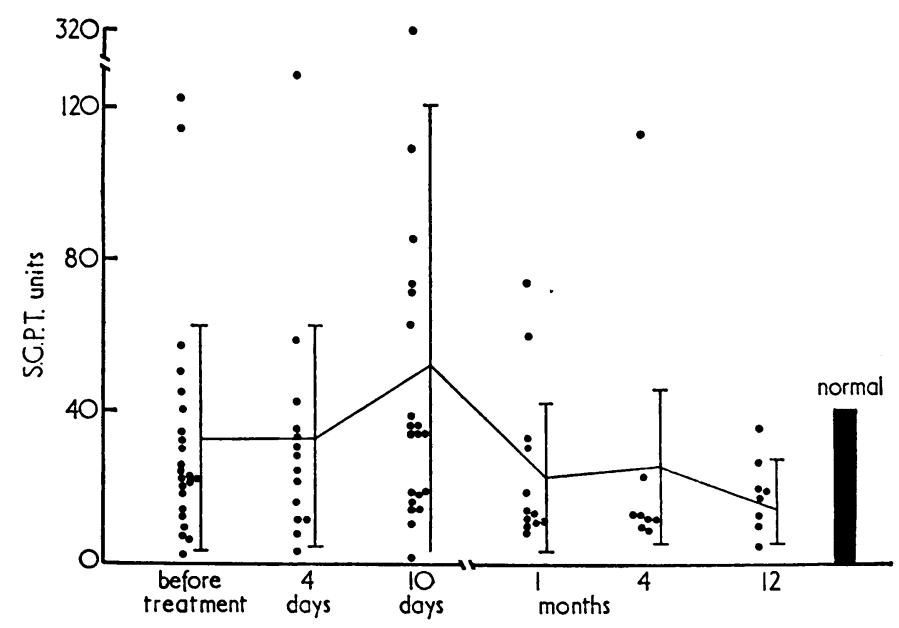

FIG. 2.-S.G.P.T. activities ( \pm S.D.) during the trial.

the course of intravenous therapy the S.G.P.T. values had a similar tendency to increase to the S.G.O.T. levels, but as therapy continued no further raised S.G.P.T. values were observed. The S.G.P.T. values which had been above normal level before treatment returned to normal in two patients during oestrogen therapy. The B.S.P. retention was slightly increased in eight patients before treatment (Fig. 3). During the intravenous oestrogen therapy B.S.P. retention increased in about $50 \%$ of the patients. At the end of the follow-up period B.S.P. retention showed raised values in four patients out of nine. 
In six patients the serum bilirubin content increased temporarily during oestrogen therapy (with a maximum of $2.3 \mathrm{mg}$./ $100 \mathrm{ml}$.) (Fig. 4). Patients who had increased B.S.P. values

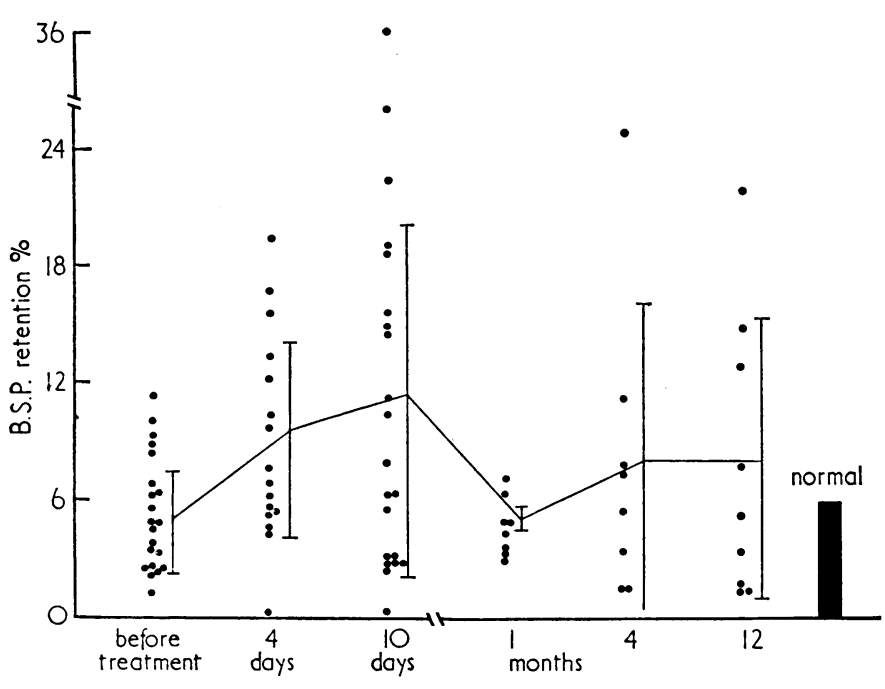

Fig. 3.-B.S.P. retention ( \pm S.D.) during the trial.

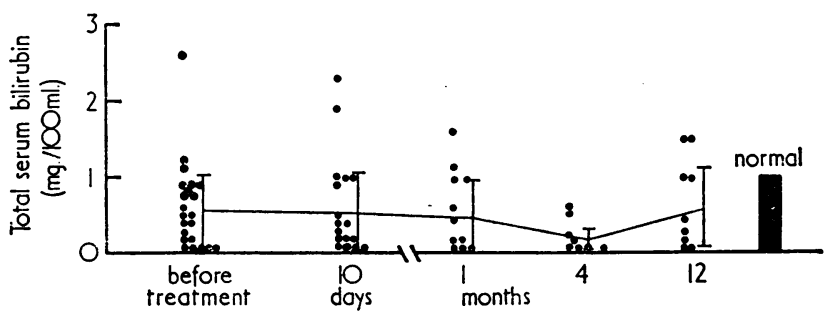

FIG. 4.-Serum bilirubin content $( \pm$ S.D.) during the trial.

during oestrogen therapy usually also had increased S.G.O.T. and S.G.P.T. values. A tendency towards a simultaneous return to normal was noted in these test values when continuing oestrogen therapy. Of the six patients whose bilirubin values were above normal three showed simultaneously increased S.G.O.T. and S.G.P.T. values. Before treatment the alkaline phosphatase content was raised in nine patients (Fig. 5).

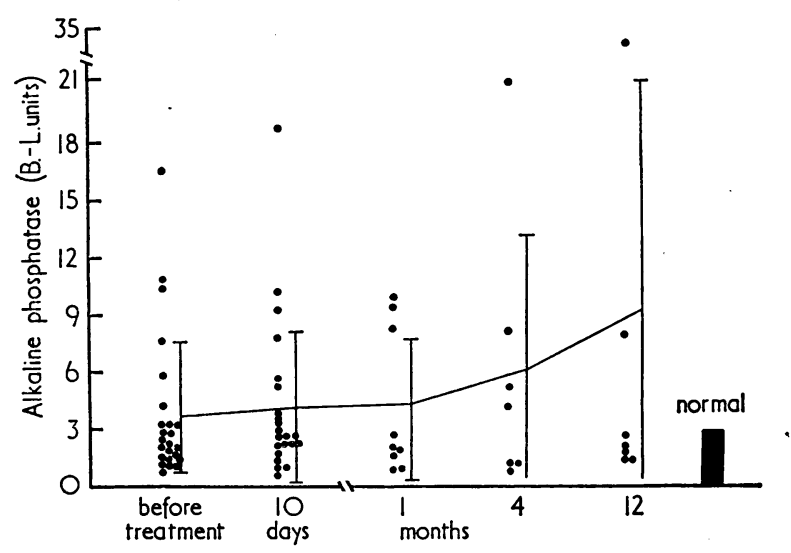

FIG. 5.-Alkaline phosphatase values ( \pm S.D.) during the trial.

During the intravenous oestrogen therapy alkaline phosphatase values showed no tendency to increase. During the oral oestrogen therapy alkaline phosphatase values in some patients increased and in some it decreased. The serum thymol turbidity test before starting therapy gave an increased value in one patient. In the course of treatment it returned to normal. During oral administration the thymol turbidity test in one patient gave an increased value of 7.9 units.

\section{Discussion}

In the early phase of oestrogen therapy the liver-function tests showed raised values in $30-50 \%$ of the patients. The most pronounced changes were a rise in serum transaminase and in B.S.P. retention. As therapy continued the increased values of S.G.O.T. and S.G.P.T. returned to normal ; however, in B.S.P. retention raised values were observed much later. The results showed a tendency similar to those recorded in connexion with the use of oral contraceptives (Borglin, 1965; Sontaniemi and Järvinen, 1966). Before treatment liver-function tests showed increased values in some patients, possibly due to liver metastases. These higher values usually became normal during oestrogen therapy. No serious liver damage necessitating interruption of the oestrogen therapy was observed in any of the patients.

The individual alkaline phosphatase level may depend on the presence of metastases in the bones, and hence this test is not suitable when examining liver function in patients with prostatic cancer. Kletschke (1959) described the cases of four prostatic cancer patients who in the early phase of oestrogen therapy developed pronounced icterus, which disappeared after discontinuance of treatment. Restarting oestrogen therapy with the same drug no longer caused dysfunction of the liver. The present results, and the findings by Kletschke, seem to indicate that when oestrogen therapy of prostatic cancer patients is continued the capacity of the liver to tolerate synthetic oestrogen increases. Probably as a : sult of enzyme induction the toxic effects on the liver cell are reduced.

What can be learnt from the present results regarding oestrogen treatment of the patient with prostatic cancer? It has been claimed that synthetic oestrogens exert a direct influence on the tumour cell (Persky and Leuchtenberger, 1957 ; Hollander et al., 1969 ; Desberg, 1960). For this reason prostatic cancer patients who at the time of diagnosis already have extensive bone metastases should be given a larger dose of oestrogens than other patients (Jönnson, 1964). These patients run an unusually high risk of acquiring an iatrogenic liver lesion. Our results show that during oestrogen therapy great individual variations occur in hepatic function tests of prostatic cancer patients. Thus oestrogen therapy should be adjusted to the patients' liver-function tests. Furthermore, patients with a history of a liver disease are known to be more sensitive to the toxic effects of synthetic hormones-for example, in viral hepatitis (Sotaniemi et al., 1964), gall bladder obstruction (Tyler, 1964), or attacks of biliary colic (Adlercreutz and Ikonen, 1964). Hence the patient's medical history should be borne in mind when oestrogen therapy is being considered.

\section{REFERENCES}

Adlercreutz, H., and Ikonen, F. (1964). British Medical fournal, 2, 1133.

Borglin, N. E. (1965). British Medical fournal, 1, 1289.

Clinch, J., and Tindall, V. R. (1969). British Medical fournal, 1, 602.

Desberg, D. (1960). Fournal of Urology, 83, 463.

Hagemann, E. (1955). Zeitschrift für Urologie Sonderband der Hamburger Kongressbericht der Deutsche Gesellschaft für Urologie, p. 56

Helrich, Ch. (1962). Inaugural Dissertation, Universität der Freiburg im Breisgau.

Hollander, V. P., Smith, D. E., and Adamson, T. E. (1959). Cancer (Philadelphia), 12, 135

Jönsson, G. (1964). In Om hormoner och hormonterapi, edited by $\mathrm{V}$. Borell, p. 174. Göteborg, Wezäta.

Kletschke, H. G. (1959). Zeitschrift für Urologie, 52, 615.

Klosterhalfen, H. (1959). Zeitschrift für Urologie, 52, 354

Persky, L., and Leuchtenberger, C. (1957). Fournal of Urology, 78, 788. Roman, W., and Hecker, R. (1968). Medical fournal of Australia, 2, 682. Sotaniemi, E., and Järvinen, P. A. (1966). Proceedings of the Society for the Study of Drug Toxicity, 8, 208. Sotaniemi, E., Kreus, K. E., and Scheinin, T. M. (1964). British Medi-
cal Fournal, 2, 1264 .

Stirling, W. C. (1945). Fournal of Urology, 53, 154

Taupitz, A. (1963). Medizinische Welt, 1116.

Tyler, E. T. (1964). Applied Therapeutics, 6, 507.

Wattenberg, C. A. (1946). Fournal of Urology, 55, 631. 